\title{
Engineering geological evaluation of Mfensi and Afari clay deposits for liner application in municipal solid waste landfills
}

\author{
Emmanuel Endene ${ }^{1}$ D .S. S. R. Gidigasu² ${ }^{2}$ S. K. Y. Gawu²
}

Received: 26 June 2020 / Accepted: 12 November 2020 / Published online: 28 November 2020

(c) Springer Nature Switzerland AG 2020

\begin{abstract}
Mfensi and Afari clay deposits in the Ashanti Region of Ghana were evaluated for their suitability as liner materials to curtail leachate migration in municipal solid waste landfills. Chemical, mineralogical, physicochemical, geotechnical, and thermal analyses were conducted to characterize the clays as well as to evaluate their potential as suitable barrier materials. The test results were compared with standard requirements for clay liner applications. The findings revealed that the chemical compositions of both clays were analogous with dominant oxides being silica, aluminum, and iron. Quartz, kaolinite, and magnetite were the minerals identified in both clays. The effective cation exchange capacity of the Mfensi and Afari clays was $5.45 \mathrm{meq} / 100 \mathrm{~g}$ and $28.99 \mathrm{meq} / 100 \mathrm{~g}$, respectively. The clays were fine-grained $(<0.06 \mathrm{~mm})$, with fines contents of approximately $80 \%$ and $56 \%$ for Mfensi and Afari clays, respectively. The Atterberg limits consisting of the liquid limits and plasticity indices of the Mfensi and Afari clays were $42.85 \%, 22.43 \%$, and $64.78 \%, 40.52 \%$, respectively. The unconfined compressive strengths were $331.73 \mathrm{kPa}$ and $242.92 \mathrm{kPa}$ for Mfensi and Afari clays, respectively. The hydraulic conductivities of the clays were of the order $\times 10^{-7} \mathrm{~cm} / \mathrm{s}$. The average thermal conductivities of the clays were found to be $0.025 \mathrm{Wm} / \mathrm{K}$ for Afari clay and $0.215 \mathrm{Wm} / \mathrm{K}$ for Mfensi clay. The results demonstrate that both clays generally passed the requirements for clay liner application and hence could be used as liner materials in municipal solid waste landfills to minimize leachate migration.
\end{abstract}

Keywords Municipal solid waste · Clay liner · Landfill · Mfensi clay · Afari clay

\section{Introduction}

Since the dawn of humanity, humans have generated and discarded waste. Discarding waste in the past did not pose a significant threat due to the nomadic pattern of settlement. However, with the advent of stable societies came waste accumulation in these communities, posing severe health and environmental risks. Developing a proper system for managing these wastes has posed a difficult and complex challenge for society in present times [1]. However, some conventional methods of dealing with solid wastes include composting, incineration, recycling, and landfilling, to name a few. Landfills have proven to be a common and frequently used waste disposal method due to its cost-effectiveness, simplified technique, and large capacity [2-5]. Notwithstanding, landfills also pose challenges such as environmental degradation and groundwater contamination resulting from the generated leachate and gas $[6,7]$. To prevent groundwater contamination and environmental degradation by

\section{Electronic supplementary material The online version of this article (https://doi.org/10.1007/s42452-020-03887-5) contains supplementary material, which is available to authorized users.}

Emmanuel Endene, emmanuel.endeneche@monash.edu $\mid{ }^{1}$ Civil Engineering Discipline, School of Engineering, Monash University Malaysia, Jalan Lagoon Selatan, 47500 Bandar Sunway, Selangor, Malaysia. ${ }^{2}$ Geological Engineering Department, Kwame Nkrumah University of Science and Technology, Kumasi, Ghana. 
the generated by-products, geosynthetic clay liners and/ or natural clayey soils are commonly used as liner materials in engineered landfills, and their merits and demerits have been discussed extensively by $[8,9]$. However, natural clayey soils are commonly used because the materials are naturally occurring, readily available, and relatively inexpensive when on-site or in close proximity [10-12]. Rowe [13] found that although both geosynthetic clay liners and natural clay liners are susceptible to desiccation and crack development, natural clays are capable of healing the cracks when there is an influx of water (self-healing property). As such, there is a growing interest in the use of natural clays as liner materials for landfill development in developing countries like Ghana, where enormous quantities of waste are generated.

Kumasi, the capital of the Ashanti Region of Ghana, is burdened with waste management problems. In 1995, the rate of municipal solid waste (MSW) generation in Kumasi was estimated at 600 tons per day. By 2005, 1000 tons of solid waste was generated each day in the city; three years later, 1200 tons was generated a day, and by 2010, 1500 tons of waste was generated in Kumasi each day [14]. Currently, there exist no data on MSW in Ghana. However, a survey conducted by Meiza et al. [15] revealed that $0.47 \mathrm{~kg}$ rate of waste is generated per person per day in Ghana, which translates into about 12,710 tons of waste per day per the current population of $27,043,093[16,17]$. Nonetheless, these numbers are expected to increase due to rapid urbanization. Because there is only one landfill site at Dompoase (Oti landfill) in the Kumasi area, open refuse dumping is commonly practiced, usually around the city's perimeter in open lots, wetland areas, or next to surface water sources [18]. This practice poses a lot of danger to the environment. In 2014, the French government granted two million Euros to construct additional cells with geosynthetic liner materials at Dompoase in the Ashanti Region [19]. These new cells are not adequate to fully cater to the ever-growing waste generated in Kumasi and its environs. Also, the problems associated with using the geosynthetic liner material, such as cost, technical limitations, and uncertainty of its performance over a period of time, are significant challenges. Therefore, the need to construct more landfills and the use of suitable liner materials such as natural clays within economic haulage distances is of importance.

Mfensi and Afari clay deposits are extensively distributed in the Ashanti Region of Ghana. Both clays occur in significant quantities, covering an approximate reserve (tons) of 396,548 and 2,055,900 for Mfensi and Afari clays, respectively [20]. The clays are derived from the various rock formations through weathering, erosion, and sedimentation and are mostly alluvial or residual in origin [20]. Due to their high water content, the clays are naturally soft and composed mainly of silicon, aluminum, and iron oxide. The main mineral constituents of both clays are quartz and kaolinite in different concentrations [21]. Previous studies have revealed that, since the establishment of the Kwame Nkrumah University of Science and Technology (KNUST), Kumasi, the Ceramics, Sculpture, Design, and Foundary Departments, as well as the Department of Integrated Rural Art and Industry, have depended solely on these clays for teaching, research, and the fabrication of ceramic products [22]. They have also been evaluated for pozzolana and bricks production by the Building and Road Research Institute (BRRI), Ghana. Moreover, the availability of these clays in commercial quantities have caused indigenes in the Afari and Mfensi communities to establish small-scale pottery industries, producing wares such as grinding bowls, palm wine pots, water coolers, burnt bricks, and building materials. [22].

Aside the numerous applications of these clays, it appears that little to no study has been done to determine their suitability as liner materials in MSW containment systems. The traditional geotechnical properties of both clays have been studied in the past. The findings indicate that both clays possess suitable geotechnical properties to be used in the construction of landfill bottom liners in terms of particle size, plasticity characteristics, and swelling properties [21, 22]. Besides, their low thermal conductivity, chemical inertness over a relatively wide range of $\mathrm{pH}$, as well as the economic appeal for using the natural geomaterial for liner application may boost their utilization as liner materials. In this context, compacted natural Mfensi and Afari clays could be used to construct landfill bottom liner materials. Despite this great potential, their use as liner materials is still not fully embraced due to the limited information available on their engineering geological properties. In view of this, this study sought to assess the engineering geological properties of Afari and Mfensi clay deposits in the Ashanti Region (Ghana) to determine their suitability for use as liner materials in MSW landfills. The findings of this study would provide a detailed understanding of the engineering geological properties of both clays, and it will motivate the utilization of the clays as bottom liner materials in MSW landfills.

\section{Materials and methods}

\subsection{Materials}

Because natural clays are known to vary spatially, steps were employed to choose a specific geographical site presumably containing the representative Afari and Mfensi clays (Fig. 1). An extensive literature review was conducted on previous studies of Afari and Mfensi clays in the Ashanti 
Fig. 1 Geological map of the Ashanti Region indicating sampled locations
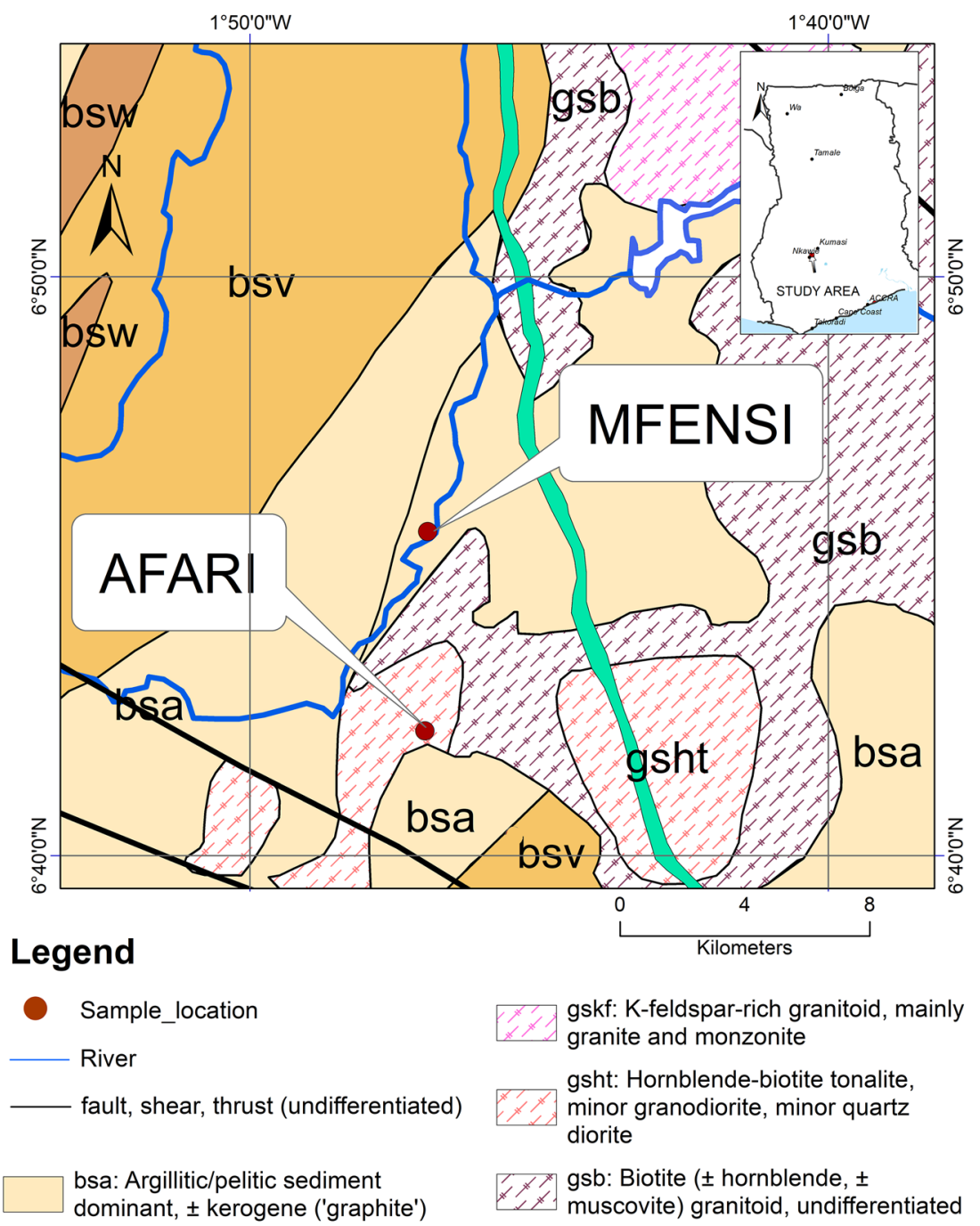

gskf: K-feldspar-rich granitoid, mainly granite and monzonite

gsht: Hornblende-biotite tonalite, minor granodiorite, minor quartz diorite

gsb: Biotite ( \pm hornblende, \pm muscovite) granitoid, undifferentiated
Region of Ghana to acquire both clays' location. Consequently, it was found that the Afari and Mfensi clay samples utilized by Amoanyi et al. [22] had possessed high fine (clay + silt) size content in their natural states, both of which generally could be suitable for liner application based on their particle size. Hence, the sites used by Amoanyi et al. [22] were chosen and tracked for soil collection. The clay samples were collected by disturbed sampling from pits located in Mfensi and Afari, both villages in the Ashanti Region of Ghana. The locations of the sites are shown in Fig. 1. The Mfensi area lies within longitudes $6^{\circ}$, $45^{\prime}$ and $6^{\circ}, 36.5^{\prime} \mathrm{N}$ and latitudes $01^{\circ}, 46^{\prime}$ and $01^{\circ}, 53.3^{\prime} \mathrm{W}$, whereas Afari is bounded by longitudes $6^{\circ}, 42^{\prime}$ and $6^{\circ}, 11^{\prime \prime}$ $\mathrm{N}$ and latitudes $01^{\circ}, 46^{\prime}$ and $01^{\circ}, 56.5^{\prime} \mathrm{W}$. The Afari site is underlain by hornblende-biotite tonalite, minor granodiorite, and minor quartz diorite, while the Mfensi site is underlain by sericite-schist, quartz-sericite schist, and locally with garnet [23]. A total of eight points/areas were selected, four in each village for sampling using a trial pit method. The dimensions of the pits were $1.5 \mathrm{~m}$ length by $1 \mathrm{~m}$ breadth by $3.0 \mathrm{~m}$ depth. The test pits were dug using a pickaxe and shovel up to a depth of $2.5 \mathrm{~m}$ and augered employing a hand-operated auger to $3 \mathrm{~m}$. Sampling was done laterally and vertically to minimize the effect of variations in the clays' physical properties. Samples from each area were combined to produce one representative material for analysis because the physical variations (color and texture) were not so different, probably due to similar soil formation processes. The samples were bagged, labeled, and transported to the laboratory for studies. Approximately $50 \mathrm{~kg}$ of each clay type was obtained. Typical grab samples of both Afari and Mfensi clay samples are presented in Fig. 2a, b, respectively.

\subsection{Methods}

The clay samples were air-dried at room temperature $\left(25-28^{\circ} \mathrm{C}\right)$ for about three weeks. The dried samples were 
Fig. 2 a Afari clay samples. b Mfensi clay samples

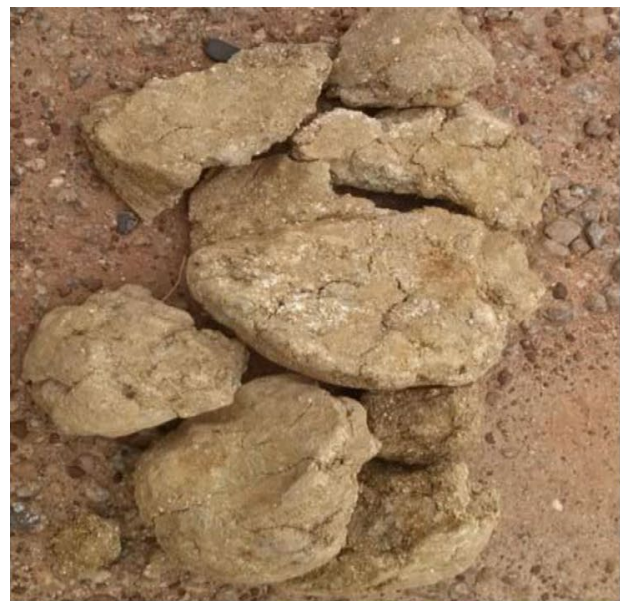

a Afari clay samples

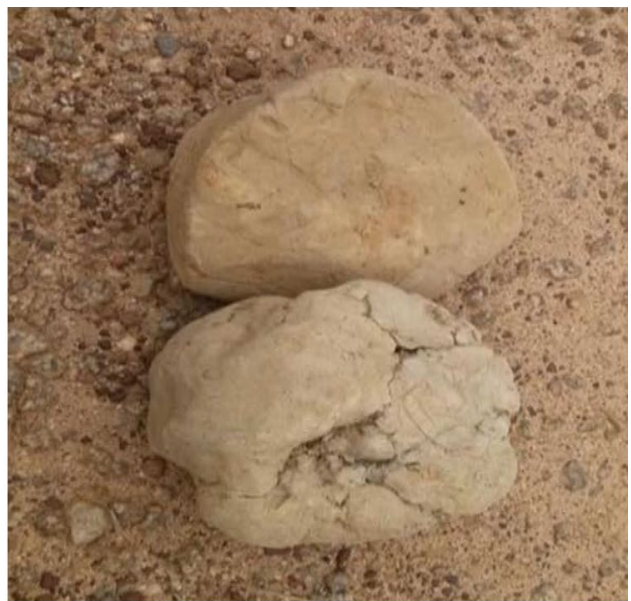

b Mfensi clay samples then pulverized prior to testing using a mortar and pestle. The pulverized samples were then subjected to chemical, mineralogical, physicochemical, geotechnical, and thermal analyses employing standard methods and are briefly discussed. The physical properties of the clays, thus soil color and texture, were determined based on visual and feel, respectively.

The clays' chemical compositions were determined using the X-ray fluorescence spectrometer (SPECTRO Analytical Instruments Inc.-X-LAB 2000, Kleve, Germany) method at the Geological Survey Department in Accra. Clay samples passing through sieve No. 200 were used for the test; $4 \mathrm{~g}$ of the samples was mixed with $0.9 \mathrm{~g}$ of powder Licowax binder and later placed in a homogenizer for complete mixing at a frequency of $15 \mathrm{~Hz}$ for $3 \mathrm{~min}$. The samples were removed and placed in a compressor and pressed under $5000 \mathrm{~g}$ of load to obtain the sample pellets of $15 \mathrm{~mm}$ in diameter. Finally, the pellets were transferred to the Spectro X-LAB 2000 for their chemical analysis determination. Measurements were taken using an excitation source that emits Ag-K X-rays (22.1 keV), in which case all elements with lower characteristic excitation energies were accessible for detection in the samples. The system consists of a Si(Li) detector with a resolution of $170 \mathrm{eV}$ for the $5.90 \mathrm{keV}$ line, coupled to a computer-controlled ADC card. Duplicate tests were conducted on both clay samples to improve the accuracy, and the mean values were reported. The major oxides and minor elements of the duplicate tests are also presented in Table 1 of the supplementary material, for the sake of completeness.

The physicochemical characteristics of the clays, such as $\mathrm{pH}$, organic matter content, and cation exchange capacity (CEC) were determined using standard procedures at the Soil Science Laboratory of the Faculty of Agriculture and Natural Resource, Kwame Nkrumah University of Science \& Technology. The CEC of the samples was determined by summing the exchangeable cations, including calcium, magnesium, potassium, and sodium, extracted using the Mehlich-3 (M3) extraction solution and methods [24]. The exchangeable acidity was determined using the titration method [25]. Walkley and Black method was employed to determine the organic matter content [26]. The $\mathrm{pH}$ was determined using the $\mathrm{pH}$ meter (Palintest Micro800 MULTI, Gateshead, UK) following standard procedures outlined in [27]. In order to improve the accuracy of the results, duplicate tests were conducted on both clay samples, and the mean values were reported. For the sake of completeness, the physicochemical characteristics of the duplicate tests are also presented in Table 2 of the supplementary material.

The mineralogical compositions of the clays were determined by the X-ray diffraction method (XRD) (Siemens D5000, Munich, Germany) with copper tube anode at a generated current of $40 \mathrm{~mA}$ and voltage of $40 \mathrm{kV}$. The scan performed was recorded at an angle scan $(2 \theta)$ between $10^{\circ}$ and $50^{\circ}$ with a step size of $0.02^{\circ}$.

The geotechnical properties determined included particle size distribution, specific gravity, natural moisture content, Atterberg limits, and linear shrinkage. These tests were performed according to standard procedures outlined in [27]. The moisture-density relationships of the clays were determined using the Standard Proctor method in accordance with [27]. The unconfined compressive strength (UCS) test was performed on the samples remolded at optimum moisture content (OMC), so as to achieve maximum density. The tests were conducted on cylindrical samples with length and diameter of 100 and $50 \mathrm{~mm}$, respectively. The samples were then tested for the UCS using the ELE compression test machine with a rate strain of $1 \mathrm{~mm} / \mathrm{min}$ applied by the ramp until the failure of the sample, following standard procedures presented in [27]. The hydraulic conductivities of the 
clays were determined using the falling head permeameter following standard procedures presented in [27]. A detailed discussion of the saturation procedure, hydraulic conductivity testing procedures, and termination criteria are reported in [11]. The falling head was used because it is most suitable for fine-grained soils such as clays. The thermal conductivities of the clays were determined by a steady-state method using the Lee disc apparatus, and a detailed description of this method is stipulated in [28]. Duplicate tests were conducted on both clay samples, and the mean values were reported. For the sake of completeness, the geotechnical properties of the duplicate tests are also presented in Table 3 of the supplementary material. The data obtained were analyzed using IBM SPSS statistic 20 and Origin 9.0 softwares.

\section{Results and discussion}

\subsection{Nature, color, texture, and chemical characteristics of the clays}

Both clays were soft with high water content. Afari clay was yellowish with shades of orange, while Mfensi clay was greenish grey in color in their dry states. Both clay types were fine-grained and lumpy.

The chemical compositions of the clays in terms of the major oxides and minor elements are presented in Table 1. It is observed that the clays have similar chemical composition with variations in their concentrations. The dominant oxides in both clays were $\mathrm{SiO}_{2}, \mathrm{Al}_{2} \mathrm{O}_{3}$, and $\mathrm{Fe}_{2} \mathrm{O}_{3}$, which constituted about $89.85 \%$ of Mfensi clay and $80.01 \%$ of the Afari clay. The Mfensi clay had an $\mathrm{Al}_{2} \mathrm{O}_{3}$ content of $25.60 \%$, making the clay fall under the class of aluminosilicate refractories [29]. Other major oxides in both clays included $\mathrm{Na}_{2} \mathrm{O}, \mathrm{MgO}, \mathrm{MnO}, \mathrm{TiO}_{2}, \mathrm{CaO}$, and $\mathrm{K}_{2} \mathrm{O}$, among others. The concentrations of these oxides were much higher in Afari clay than Mfensi clay except for $\mathrm{TiO}_{2}, \mathrm{Al}_{2} \mathrm{O}_{3}$, and $\mathrm{K}_{2} \mathrm{O}$. It is also noted that, among the minor elements analyzed, the concentrations of $\mathrm{Co}, \mathrm{Ni}, \mathrm{Sr}, \mathrm{Ba}, \mathrm{La}$, and $\mathrm{Ce}$ were more prominent in Afari clay than in Mfensi clay. In the Mfensi clay, Zr, Ba, Rb, Ce, Sr, La, and Zn were higher than the other minor elements. Ba was found to have the highest concentration in Afari clay with $886 \mathrm{ppm}$, while in the Mfensi clay, it was Zr with 553 ppm.

\subsection{Physicochemical characteristics of the clays}

The physicochemical characteristics of the clays are presented in Table 2. The pHs of the clays were 5.37 and 5.29 for Afari and Mfensi clays, respectively, which indicates that they are acidic. The organic matter contents of the clays were $0.48 \%$ and $1.65 \%$ for Afari and Mfensi clays,
Table 1 Chemical analysis of both Afari and Mfensi clays

\begin{tabular}{|c|c|c|c|c|}
\hline & \multicolumn{2}{|l|}{ Afari clay } & \multicolumn{2}{|c|}{ Mfensi clay } \\
\hline & Mean (\%) & SD & Mean (\%) & SD \\
\hline \multicolumn{5}{|c|}{ Major oxides } \\
\hline $\mathrm{SiO}_{2}$ & 51.47 & 0.21 & 61.19 & 0.25 \\
\hline $\mathrm{TiO}_{2}$ & 0.77 & 0.07 & 0.83 & 0.06 \\
\hline $\mathrm{Al}_{2} \mathrm{O}_{3}$ & 21.58 & 0.04 & 25.6 & 0.88 \\
\hline $\mathrm{Fe}_{2} \mathrm{O}_{3}$ & 7.06 & 0.03 & 3.06 & 0.04 \\
\hline $\mathrm{SO}_{3}$ & 0.09 & 0.01 & 0.06 & 0.00 \\
\hline $\mathrm{MgO}$ & 2.29 & 0.03 & 1.69 & 0.10 \\
\hline $\mathrm{K}_{2} \mathrm{O}$ & 0.63 & 0.03 & 1.57 & 0.10 \\
\hline $\mathrm{CaO}$ & 0.79 & 0.01 & 0.12 & 0.03 \\
\hline $\mathrm{MnO}$ & 0.03 & 0.00 & 0.02 & 0.01 \\
\hline $\mathrm{Na}_{2} \mathrm{O}$ & 1.32 & 0.03 & 0.94 & 0.00 \\
\hline $\mathrm{P}_{2} \mathrm{O}_{5}$ & 0.005 & 0.00 & 0.08 & 0.04 \\
\hline LOI (\%) & 12.62 & 0.08 & 4.00 & 1.48 \\
\hline \multicolumn{5}{|c|}{ Minor elements (ppm) } \\
\hline Co & 34.7 & 0.28 & $<19$ & 0.00 \\
\hline $\mathrm{Ni}$ & 96 & 4.24 & 15.9 & 0.85 \\
\hline $\mathrm{Cu}$ & 14.1 & 0.85 & 4.8 & 0.57 \\
\hline $\mathrm{Zn}$ & 49.2 & 0.28 & 31.3 & 1.56 \\
\hline $\mathrm{Ga}$ & 22.5 & 0.57 & 17.8 & 0.99 \\
\hline $\mathrm{Pb}$ & 1.2 & 0.00 & 2.4 & 0.42 \\
\hline $\mathrm{Ge}$ & 1.5 & 0.14 & 1.3 & 0.42 \\
\hline As & 2.1 & 0.00 & 1.4 & 0.00 \\
\hline $\mathrm{Rb}$ & 11.6 & 0.28 & 52.8 & 0.99 \\
\hline $\mathrm{Sr}$ & 443.6 & 0.71 & 37.8 & 0.71 \\
\hline$Y$ & 19.9 & 0.99 & $<0.6$ & 0.00 \\
\hline $\mathrm{Zr}$ & 339 & 0.00 & 553 & 4.24 \\
\hline $\mathrm{Nb}$ & 19.5 & 0.28 & 18 & 2.97 \\
\hline Sn & $<2.1$ & 0.00 & 1.3 & 0.42 \\
\hline Cs & $<10$ & 0.00 & 17.9 & 0.57 \\
\hline $\mathrm{Ba}$ & 886 & 2.83 & 369.6 & 0.85 \\
\hline La & 181 & 2.83 & 34.2 & 0.28 \\
\hline $\mathrm{Ce}$ & 408 & 1.41 & 51 & 2.83 \\
\hline
\end{tabular}

Table 2 Physicochemical properties of both clay samples

\begin{tabular}{|c|c|c|c|c|}
\hline \multirow[t]{2}{*}{ Properties } & \multicolumn{2}{|c|}{ Afari clay } & \multicolumn{2}{|c|}{ Mfensi clay } \\
\hline & Mean & SD & Mean & SD \\
\hline $\mathrm{pH}$ & 5.37 & 0.23 & 5.29 & 0.08 \\
\hline Organic matter (\%) & 0.48 & 0.08 & 1.65 & 0.06 \\
\hline Potassium (meq/100 g) ${ }^{a}$ & 0.10 & 0.00 & 0.20 & 0.04 \\
\hline Sodium (meq/100 g) & 1.17 & 0.07 & 0.25 & 0.01 \\
\hline Calcium (meq/100 g) & 12.16 & 0.08 & 4.02 & 0.03 \\
\hline Magnesium (meq/100 g) ${ }^{a}$ & 15.56 & 0.07 & 0.98 & 0.06 \\
\hline Aluminum $(\mathrm{meq} / 100 \mathrm{~g})^{\mathrm{b}}$ & 1.67 & 0.06 & 1.00 & 0.00 \\
\hline Hydrogen $(\mathrm{meq} / 100 \mathrm{~g})^{\mathrm{b}}$ & 1.67 & 0.08 & 1.34 & 0.06 \\
\hline CEC $(\Sigma$ cations $)$ meq $/ 100 \mathrm{~g}$ & 28.99 & 0.23 & 5.45 & 0.14 \\
\hline
\end{tabular}

CEC cation exchange capacity

${ }^{a}$ Exchangeable cations; ${ }^{b}$ exchangeable acidity 
respectively. The CEC of the clays, which is the measure of the adsorption characteristics or exchange capacity of the clay minerals and an indicator of the type and amount of free cations that are adsorbed, expressed in milliequivalent per $100 \mathrm{~g}$ of the clays [30] was found to be $28.99 \mathrm{meq} / 100 \mathrm{~g}$ for Afari clay and $5.45 \mathrm{meq} / 100 \mathrm{~g}$ for Mfensi clay. There are no widely accepted minimum specifications for CEC values for liner materials. However, researchers such as Rowe et al. [31] and Kayabali [32] have recommended that soil liner materials should have at least a CEC of $10 \mathrm{meq} / 100 \mathrm{~g}$ for a better adsorption characteristic; thus, Mfensi clay failed to meet the requirement.

\subsection{Mineralogical composition of the clays}

The X-ray diffractograms of both clays showed similar phases indicating similar mineralogy, as shown in Figs. 3 and 4. They indicate that both clays were composed of Kaolinite (as clay mineral) and Quartz and Magnetite as non-clay minerals in varying concentrations, as reflected in the intensities and peak heights of the $\mathrm{X}$-ray diffractograms. Overlapping of the clay and non-clay minerals in both clays are common. The presence of the clay mineral kaolinite in both clays implies that the clays are likely to perform effectively as barrier soils in containment and attenuation of contaminants generated [33]. The presence of kaolinite also indicates that they will exhibit low to moderate shrinkage on drying and low to moderate expansion on wetting since kaolinite has the least affinity for water among the clay minerals with greater stability and confining ability [34]. It is noted that strong quartz peaks were detected in both diffractograms,

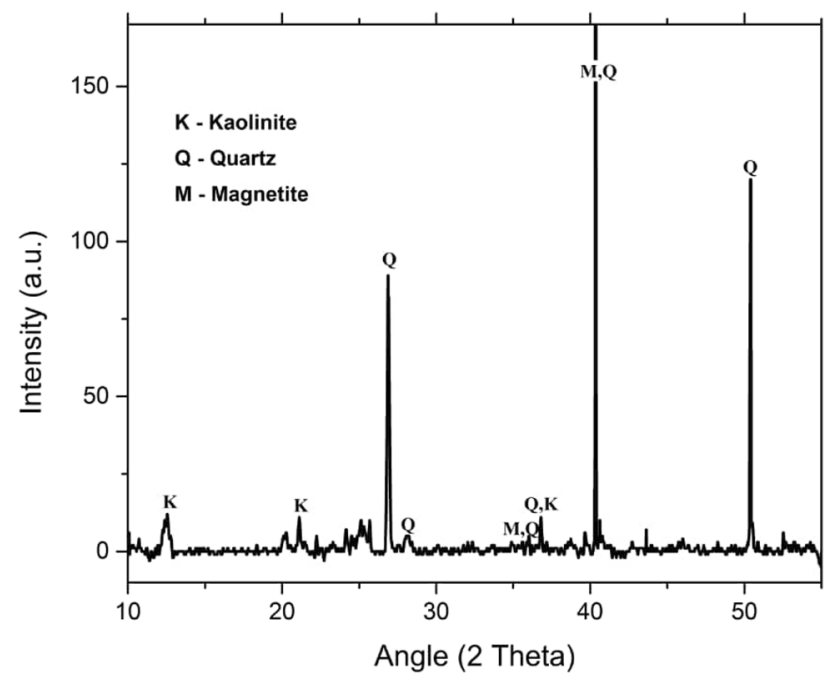

Fig. 3 X-ray diffraction pattern of Afari clay sample

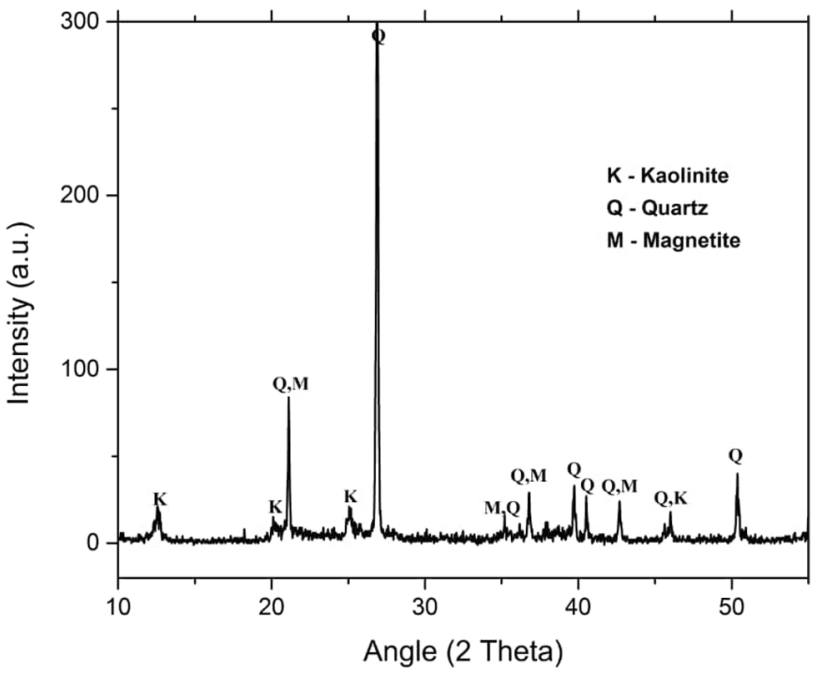

Fig. 4 X-ray diffraction pattern of Mfensi clay sample

which can be attributed to the high concentration of $\mathrm{SiO}_{2}$ in both clays [22], which is also demonstrated in the XRF analysis.

\subsection{Geotechnical characteristics of the studied clays}

The geotechnical characteristics of the clays are summarized in Table 3.

\subsubsection{Specific gravity and natural moisture content}

The average specific gravities of Afari and Mfensi clay samples were 2.68 and 2.72 , respectively, and were found to be above 2.5 , which is the minimum recommended for liner materials by the $[35,36]$. The natural moisture contents of both clays were $29.09 \%$ and $33.40 \%$ for Afari and Mfensi clays, respectively.

\subsubsection{Atterberg limits and plasticity characteristics}

The Atterberg limits of Afari clay were higher than those of Mfensi clay. The liquid limit and plasticity index of the Afari clay were $64.78 \%$ and $40.52 \%$, whereas those for the Mfensi clay were $42.85 \%$ and $22.43 \%$, respectively. Qian et al. [37] recommended that clays with a plasticity index $>10 \%$ should be utilized for liner application. Also, Mitchell and Jaber [38] suggested that, for materials to be used as baseliners, the liquid limit should be $\geq 30 \%$, and the plasticity index should be $>10 \%$. Besides, Declan and Paul [39] also indicated that liner materials should not have liquid limits of more than $90 \%$. From the results, it is found that the Atterberg limits of both clays met the requirement for use as clay liner. Furthermore, the plasticity indices of both clays exceeded $10 \%$ and therefore passed the 
Table 3 Summary of results of the geotechnical characteristics of the clays

\begin{tabular}{|c|c|c|c|c|}
\hline \multirow[t]{2}{*}{ Parameters } & \multicolumn{2}{|l|}{ Afari clay } & \multicolumn{2}{|l|}{ Mfensi clay } \\
\hline & Mean & SD & Mean & SD \\
\hline \multicolumn{5}{|l|}{ Atterberg limits } \\
\hline Liquid limit (\%) & 64.78 & 3.75 & 42.85 & 4.33 \\
\hline Plastic limit (\%) & 24.26 & 3.07 & 20.42 & 3.35 \\
\hline Plasticity index (\%) & 40.52 & 0.68 & 22.43 & 0.98 \\
\hline Liquidity index (\%) & 0.12 & 0.04 & 0.58 & 0.16 \\
\hline Linear shrinkage (\%) & 17.7 & 0.57 & 10.4 & 0.57 \\
\hline Specific gravity (Gs) & 2.68 & 0.04 & 2.72 & 0.03 \\
\hline $\begin{array}{l}\text { Natural moisture content } \\
\text { (\%) }\end{array}$ & 29.09 & 0.13 & 33.4 & 2.29 \\
\hline Activity & 1.2 & 0.07 & 0.6 & 0.00 \\
\hline \multicolumn{5}{|l|}{ Grading } \\
\hline Sand (\%) & 43.51 & 0.82 & 20.5 & 0.10 \\
\hline Silt (\%) & 22.31 & 2.29 & 41.5 & 0.33 \\
\hline Clay (\%) & 34.17 & 1.46 & 38.33 & 0.16 \\
\hline $\begin{array}{l}\text { Fines contents (silt + clay) } \\
\text { (\%) }\end{array}$ & 56.48 & 0.83 & 79.5 & 0.17 \\
\hline \multicolumn{5}{|l|}{ Strength } \\
\hline $\operatorname{MDD}\left(\mathrm{Mg} / \mathrm{m}^{3}\right)$ & 1.539 & 0.05 & 1.625 & 0.04 \\
\hline OMC (\%) & 18.98 & 2.73 & 20.00 & 1.56 \\
\hline UCS (kPa) & 242.92 & 8.40 & 331.73 & 9.04 \\
\hline \multicolumn{5}{|l|}{ Conductivities } \\
\hline $\begin{array}{l}\text { Hydraulic conductivity } \\
(\mathrm{cm} / \mathrm{s})\end{array}$ & $4.637 \times 10-^{7}$ & 4.02 & $3.448 \times 10-^{7}$ & 3.40 \\
\hline
\end{tabular}

MDD maximum dry density, OMC optimum moisture content, UCS unconfined compressive strength

requirements [38]. However, Daniel [40] found that soils with plasticity index exceeding $35 \%$ are expected to display excessive shrinkage and settlement. Thus, Mfensi clay is better in terms of its suitability for clay liner with respect to shrinkage potential than Afari clay since its plasticity index is $<35 \%$ based on the recommendation of [40].

The plot of the liquid limit and plasticity index of the clays on the Casagrande's plasticity chart, as shown in Fig. 5 , indicates that both clays lie above the A-line. Jones et al. [41] stated that materials that fall above the A-line are suitable or marginal for use as liners, and those below the A-line are unsuitable. Based on the Unified Soil Classification System (USCS), the Afari clay could be classified as inorganic clay of high plasticity $(\mathrm{CH})$ and Mfensi clay as inorganic clay of intermediate plasticity $(\mathrm{Cl})$.

\subsubsection{Linear shrinkages of the clays}

Both samples had linear shrinkages less than $20 \%$, though Afari clay recorded a higher value than Mfensi clay. Mfensi clay recorded a value of $10.40 \%$, while Afari clay had a value of $17.7 \%$. Cracks were observed on the Mfensi clay

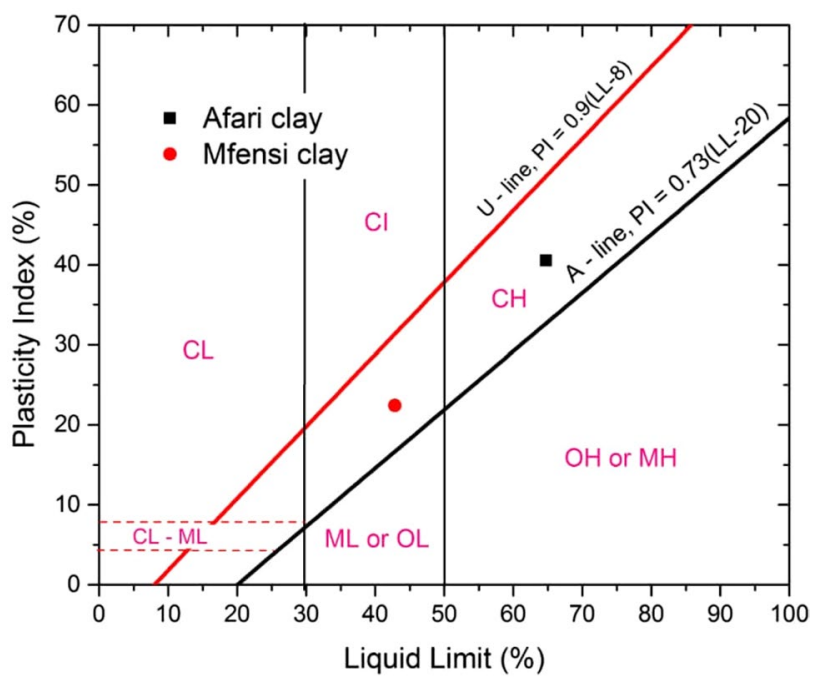

Fig. 5 Plasticity characteristics of both clays

samples after shrinkage test. Cracks were, however, absent in the Afari clay. Despite the low linear shrinkage of Mfensi clay, the formation of cracks could make it unsuitable for use as a liner material.

\subsubsection{Colloidal activity of the clays}

The colloidal activities of the clays, which is the ratio of the plasticity indices to the clay size content of the soils, were found to be 1.2 and 0.6 for Afari and Mfensi clays, respectively. This indicates that the Mfensi clay has low expansion potential, and the Afari clay has medium expansion potential, according to [42] classification. Rowe et al. [31] recommended that soils with an activity of 0.3 and above are suitable as liner material and can achieve a hydraulic conductivity of order $\times 10^{-7} \mathrm{~cm} / \mathrm{s}$.

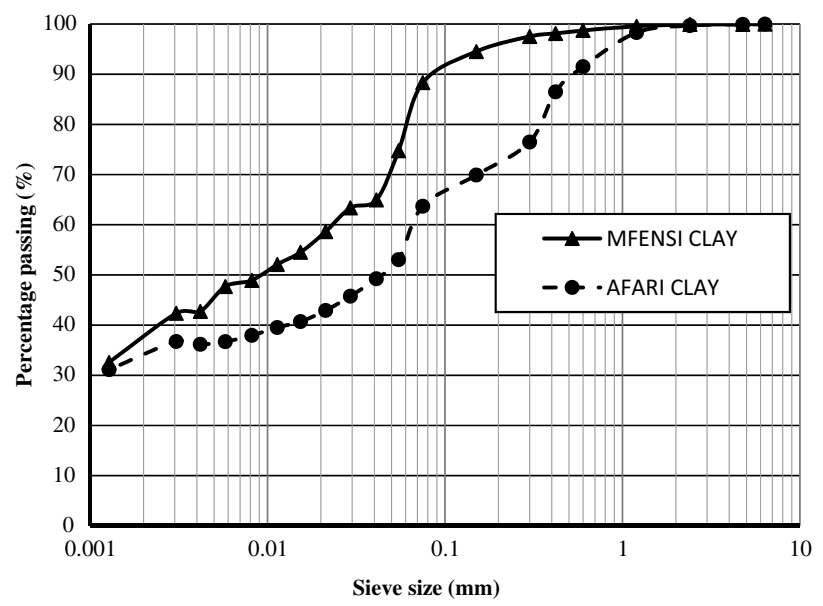

Fig. 6 Particle size distribution curves of the clays 


\subsubsection{Particle size distribution}

The particle size distributions of the two clay samples are shown in Fig. 6. The grading curves of the clays indicate that they are well graded within the sand $(0.06-2 \mathrm{~mm})$ and clay size $(<0.002 \mathrm{~mm})$ zone. It is found that the sand size contents were $43.51 \%$ for Afari clay and $20.5 \%$ for Mfensi clay, and the results are within the range proposed by [43]. They indicated that liner materials should contain adequate quantities of sand greater than $20 \%$, which would offer significant protection from volumetric shrinkage and impact adequate strength.

The silt and clay size contents were $22.31 \%$ and $34.17 \%$, respectively, for Afari clay, whereas those for Mfensi clay were $41.5 \%$ and $38.33 \%$ for silt and clay size, respectively. Both clays satisfied the recommendations of Declan and Paul [39], who proposed a minimum clay content of $10 \%$ for barrier soils. The fines content was approximately $56 \%$ and $80 \%$ for Afari and Mfensi clays, respectively, and these values fall within the recommended limits of $\geq 30 \%$ fines [44]. Brunner and Keller [45] recommended the use of finer soils as barrier materials because they have a high specific surface area. They added that there is low migration of leachate as soil texture becomes finer. EPA [46] found that liner materials should have at least $20 \%$ fines in order to achieve a hydraulic conductivity of less than $1 \times 10^{-7} \mathrm{~cm} / \mathrm{s}$. It can, therefore, be concluded that both clays satisfy the above-mentioned requirements for grading characteristics.

\subsubsection{Strength characteristics of the clays}

The compaction characteristics of the clays are presented in Fig. 7. It is noted that the maximum dry density (MDD) of Mfensi clay $\left(1.62 \mathrm{Mg} / \mathrm{m}^{3}\right)$ was higher than that of Afari clay $\left(1.54 \mathrm{Mg} / \mathrm{m}^{3}\right)$. The optimum moisture contents (OMC) were

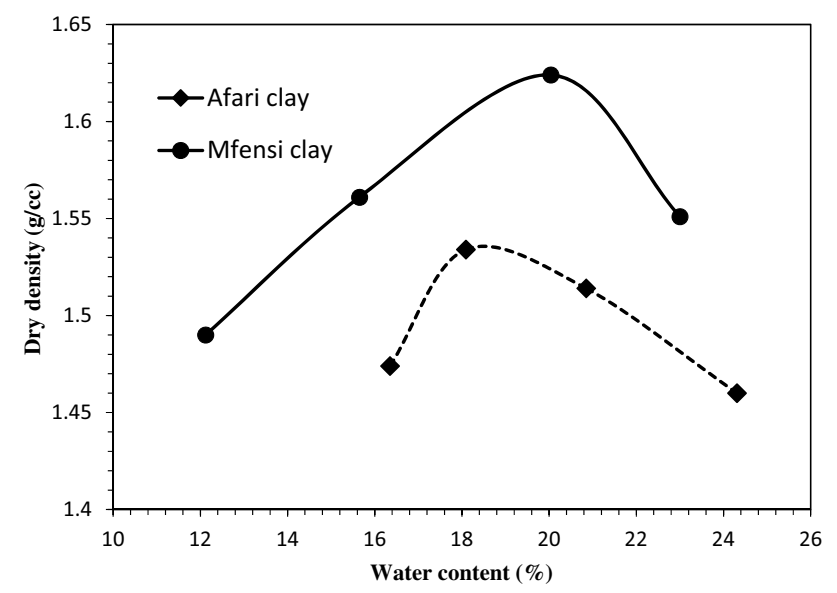

Fig. 7 Compaction characteristics of the clays
$18.98 \%$ and $20.00 \%$ for Afari and Mfensi clays, respectively. These values were significantly lower than their respective natural moisture contents of the clays.

The unconfined compressive strengths (UCS) of the clays were $331.73 \mathrm{kPa}$ and $242.92 \mathrm{kPa}$ for Mfensi and Afari clays, respectively. The high UCS recorded for Mfensi clay could be due to the high percentage of fine fractions filling the void spaces and the interlocking of the coarse grains, hence reducing compressibility, porosity, and deformation and thus increasing the shear strength characteristics. Both clays meet the strength requirement of not less than 200 kPa proposed by Daniel and Wu [44] for baseliner materials.

\subsubsection{Hydraulic conductivity of the clays}

The hydraulic conductivity for Mfensi clay was found to be lower than that of Afari clay with values of $3.45 \times 10^{-7} \mathrm{~cm} / \mathrm{s}$ and $4.64 \times 10^{-7} \mathrm{~cm} / \mathrm{s}$, respectively. The low hydraulic conductivity value of Mfensi clay could be attributed to its high clay and silt size contents, which filled the voids between the coarse particles, thus reducing the size of the pores controlling the flow and decreasing the hydraulic conductivity. The hydraulic conductivities of both clays satisfy the requirements of the order $\times 10^{-7} \mathrm{~cm} / \mathrm{s}$ or less recommended for clay baseliner materials [47].

\subsubsection{Thermal conductivities of the clays}

A study of the thermal conductivity of Afari and Mfensi clays was performed with a view of understanding their ability to conduct or transfer heat mainly for application as liner materials since the effects of heat on liner materials can result in desiccation, changes in shear strength, and hydraulic conductivity of the liner material. The Afari clay had thermal conductivity values, ranging between $0.02 \mathrm{Wm} / \mathrm{K}$ and $0.03 \mathrm{Wm} / \mathrm{K}$, with a mean value of $0.025 \mathrm{Wm} / \mathrm{K}$. On the other hand, Mfensi clay recorded thermal conductivities, which range between $0.21 \mathrm{Wm} / \mathrm{K}$ and $0.22 \mathrm{Wm} / \mathrm{K}$ with a mean of $0.215 \mathrm{Wm} / \mathrm{K}$. According to Ayugi [48], thermal conductivity increases with increasing percentage of smaller particle size (fine particles). This can be explained on the basis that smaller particles will mesh closely, leading to a better transfer of heat between them. The low thermal conductivity of the Afari clay relative to Mfensi clay could be due to its lower amount of fines contents. Afari clay had 56.48\% fines, while Mfensi had $79.5 \%$ fines content and hence that explains the phenomena observed. The clays, however, possessed the required thermal conductivities to be used as liner materials; thus, less than $2 \mathrm{Wm} / \mathrm{K}$ recommended by [49]. 


\section{Conclusion}

The study investigated the engineering geological properties of Afari and Mfensi clays in their natural state for possible use as liner materials for municipal solid waste landfill sites in Ghana. From the research, the following conclusions were made:

- The most abundant oxides of the clays are $\mathrm{SiO}_{2}, \mathrm{Al}_{2} \mathrm{O}_{3}$, and $\mathrm{Fe}_{2} \mathrm{O}_{3}$, which constituted about $89.85 \%$ of Mfensi clay and $80.01 \%$ of the Afari clay. The mineralogy of the clays from XRD analyses is similar and is composed of kaolinite, quartz, and magnetite as the main minerals.

- The effective cation exchange capacity of the Mfensi and Afari clays was $5.45 \mathrm{meq} / 100 \mathrm{~g}$ and $28.99 \mathrm{meq} / 100 \mathrm{~g}$, respectively. Thus, Mfensi clay failed to meet the minimum recommendation of at least $10 \mathrm{meq} / 100 \mathrm{~g}$ for clay liner materials.

- The clays were fine-grained $(<0.06 \mathrm{~mm})$, with fines contents of approximately $80 \%$ and $56 \%$ for Mfensi and Afari clays, respectively. Hence, these values fall within the recommended limits of $\geq 30 \%$ fines for liner materials.

- The unconfined compressive strengths were $331.73 \mathrm{kPa}$ and $242.92 \mathrm{kPa}$ for Mfensi and Afari clays, respectively. Hence, these values met the minimum UCS specification of $\geq 200 \mathrm{kPa}$ for liner materials.

- The average thermal conductivities of the clays were found to be $0.025 \mathrm{Wm}^{-1} \mathrm{~K}^{-1}$ for Afari clay and $0.215 \mathrm{Wm}^{-1} \mathrm{~K}^{-1}$ for Mfensi clay.

- Both Mfensi and Afari clays presented low hydraulic conductivities of the order $\times 10^{-7} \mathrm{~cm} / \mathrm{s}$, which corresponded with a higher content of silt and clay size fractions. The hydraulic conductivities of both clays satisfy the Ghanaian regulatory specification of the order $\times 10^{-7} \mathrm{~cm} / \mathrm{s}$ or less recommended for clay baseliner materials.

From the study, some of the requirements for liner utilization that were met included the hydraulic conductivity, thermal conductivity, unconfined compressive strength, plasticity characteristics, and particle size. However, the Mfensi clay failed to meet the recommended value for the cation exchange capacity for liner materials, and it had the tendency to develop cracks. Nevertheless, this should not be used as a basis for rejection of the material if suitable materials are not readily available within economical haulage distances. Therefore, it can be concluded that both clays are suitable for use as liner materials in MSW landfills. However, field investigations are vital for ascertaining this experimental observation. Besides, since leachate will be the main permeant experienced in the field, future works are recommended to evaluate the clays' engineering geological properties using field leachate as the permeant. Chemical stabilization may also be considered as an attractive alternative to further improve the engineering properties of the clays. Likewise, other important parameters such as diffusion and retention capacity of the clays need to be evaluated before deciding their full potential as hydraulic barriers in MSW landfills.

Acknowledgements The authors express gratitude to the Abunde Sustainable Engineering Group for its valued recommendations.

\section{Compliance with ethical standards}

Conflict of interest The authors declare that they have no conflict of interest.

\section{References}

1. Nayak S, Sunil BM, Allamaprabhu K (2014) Assessment of blended lithomargic clay as landfill liner material. Curr Adv Civ Eng 2(4):102-117

2. Maritsa L, Tsakiridis PE, Katsiotis NS, Tsiavos H, Velissariou D, Xenidis A, Beazi-Katsioti M (2016) Utilization of spilitic mining wastes in the construction of landfill bottom liners. J Environ Chem Eng 4(2):1818-1825

3. Li L, Lin C, Zhang Z (2017) Utilization of shale-clay mixtures as a landfill liner material to retain heavy metals. Mater Des 114:73-82

4. Khodary SM, Negm AM, Tawfik A (2018) Geotechnical properties of the soils contaminated with oils, landfill leachate, and fertilizers. Arab J Geosci 11(2):13

5. Emmanuel E, Anggraini V, Raghunandan ME, Asadi A (2020) Utilization of marine clay as a bottom liner material in engineered landfills. J Environ Chem Eng. https://doi.org/10.1016/j. jece.2020.104048

6. Osinubi KJ, Oluremi JR, Eberemu AO, Ijimdiya ST (2017) Interaction of landfill leachate with compacted lateritic soil-waste wood ash mixture. Proc Inst Civil Eng Waste Resour Manag. https ://doi.org/10.1680/jwarm.17.00012

7. Yong LL, Emmanuel E, Purwani R, Anggraini V (2019) Geotechnical assessment of Malaysian residual soils for utilization as clay liners in engineered landfills. Int J Geomate 16(58):20-25

8. Akayuli CFA, Gidigasu SSR, Gawu SKY (2013) Geotechnical evaluation of Ghanaian black cotton soil for use as clay liner in tailings dam construction. Ghana Min J 14:21-26

9. Emmanuel E, Anggraini V, Gidigasu SSR (2019) A critical reappraisal of residual soils as compacted soil liners. SN Appl Sci. https://doi.org/10.1007/s42452-019-0475-7

10. Emmanuel E, Anggraini V (2019) Effects of desiccation-induced cracking and leachate infiltration on the hydraulic conductivity of natural and olivine-treated marine clay. Int J Environ Sci Technol 17(4):2259-2278

11. Emmanuel E, Anggraini V, Asadi A, Raghunandan ME (2019) Interaction of landfill leachate with olivine-treated marine clay: suitability for bottom liner application. Environ Technol Innov 17:100574 
12. Narani SS, Abbaspour M, Hosseini SMM, Aflaki E, Nejad FM (2020) Sustainable reuse of waste tire textile fibers (WTTFs) as reinforcement materials for expansive soils: with a special focus on landfill liners/covers. J Clean Prod 247:119151

13. Rowe RK (2005) Long term performance if containment systems. Geotechnique 55(9):631-648

14. KMA (2010) Data for purposes of planning waste management intervention programmes. Waste management department, Kumasi metropolitan assembly Kumasi, Ghana

15. Miezah K, Obiri-Danso K, Kádár Z, Fei-Baffoe B, Mensah MY (2015) Municipal solid waste characterization and quantification as a measure towards effective waste management in Ghana. J Waste Manag 46:15-27

16. Abalo EM, Peprah P, Nyonyo J, Ampomah-Sarpong R, Agyemang-Duah W (2018) A review of the triple gains of waste and the way forward for Ghana. J Renew Energy 2018:1-12

17. Amo-Asamoah E, Owusu-Manu DG, Asumadu G, Ghansah FA, Edwards DJ (2020) Potential for waste to energy generation of municipal solid waste (MSW) in the Kumasi metropolis of Ghana. Int J Energy Sect Manag. https://doi.org/10.1108/IJESM $-12-2019-0005$

18. Owusu-Sekyere E, Osumanu IK, Yaro JA (2013) Dompoase landfill in the Kumasi metropolitan area of Ghana: a "blessing" or a "curse"? Int J Curr Res 2(1):87-96

19. Graphic Online (2014) Kumasi to get new landfill site. http:// graphic.com.gh/news/general-news/30956-kumasi-to-getnew-landfill-site.html\#sthash.tBKZ3b6E.dpuf. Assessed on 27 July 2015

20. Kesse GO (1985) The mineral and rock resources of Ghana. A. A Balkema, Rotterdam, p 612

21. Andrews A, Gawu SKY, Appiah M, Indome A, Fudzi A, Abakah $J$ (2014) Strength of lithomargic clay based refractories after thermal cycling. Refract Ind Ceram 55(2):143-147

22. Amoanyi R, Kwawukume PS, Momade FW (2012) Improving the strength properties of Afari and Mfensi clays by chemical stabilization. Int J Eng Res Afr 8:1-15

23. Ghana Geological Survey Department (2009) The geological map of Ghana with explanatory notes, 1:1000000, Ghana Geological Survey/Bundesanstalt fur Geowissenschaften und Rohstoffe (Germany)

24. Mehlich A (1984) Mehlich 3 soil test extractant: a modification of Mehlich 2 extractant. Commun Soil Sci Plan 15(12):1409-1416

25. Yuan TL (1959) Determination of exchangeable hydrogen in soils by a titration method. Soil Sci 88(3):164-167

26. Walkley A, Black IA (1934) An examination of the Degtjareff method for determining soil organic matter, and a proposed modification of the chromic acid titration method. Soil Sci 37(1):29-38

27. BS 1377 (1990) Methods of testing soils for civil engineering purpose. British-Standards Institution, London

28. ASTM D5470-06 (2006) Standard test method for thermal transmission properties of thermally conductive electrical insulation materials. ASTM International, West Conshohocken

29. Hassan SB, Adewara JOT (1993) Refractory properties of some Nigerian clays. NSE Tech Trans 28(3):13-19

30. Abdussalam AS (2005) The suitability of the Libyan soils for use as engineered landfill liners. Ph.D. Thesis Loughborough University

31. Rowe RK, Quigley RM, Booker JR (1995) Clayey-leachate compatibility by measurement of hydraulic conductivity. Clay barrier systems for waste disposal facilities, E and FN Spoon. Chapman and Hall, London

32. Kayabali K (1997) Engineering aspects of a novel landfill liner material: bentonite amended natural zeolite. Eng Geol 46:105-114

33. Allen AR (2000) Attenuation landfills: the future in landfilling. Pol Environ Eng J 2:365-381

34. Oyediran IA, Iroegbuchu CD (2013) Geotechnical characteristics of some southwestern Nigerian clays as barrier soils. IFE J Sci 15(1):17-30

35. ONORM, S 2074 (1990) Geotechnik in Deponiebau Erdarbeiten Osterreichisches. Normungsinstitut, Wien

36. United States Environmental Protection Agency (1982) Hazardous waste management systems: permitting requirements for land disposal facilities

37. Qian X, Koerner RM, Gray DH (2002) Geotechnical aspects of landfill design and construction. Prentice Hall, Upper Saddle River, $\mathrm{p} 717$

38. Mitchell JK, Jaber M (1990) Factors controlling the long term properties of clay liners. Waste containment systems. Construction, regulation and performance. In: Bonaparte R (ed) Geotechnical special publication No. 26. ASCE, San Francisco, California

39. Declan O, Paul Q (2003) Geotechnical engineering and environmental aspects of clay liners for landfill projects. www.igsl.ie/ Technical/Paper3.doc. Fehily Timoney \& Co. \& IGSL Limited

40. Daniel DE (1991) Design and construction of RCRA/CERCLA final covers, chapter 2: soils used in cover systems. EPA/625/4-91/025, US EPA, Cincinnati, Ohio

41. Jones RM, Murray EJ, Rix DW (1993) Selection of clays for use as landfill liners. waste disposal by landfill. Proc Symp Green 93:433-438

42. Skempton AW (1953) The colloidal activity of clay. In: Proceedings of the third international conference on soil mechanics and foundation engineering, vol 1, pp. 57-61

43. Kabir H, Taha MR (2004) Assessment of physical properties of granite residual soil as an isolation barrier. Electron J Geotech Eng 9(0408):13p

44. Daniel DE, Wu YK (1993) Compacted clay liners and covers of arid sites. J Geotech Eng ASCE 199(2):223-237

45. Brunner DR, Keller DJ (1972) Sanitary landfill design and operation. U. S. Environmental Protection Agency

46. EPA (1990) Compilation of information on alternative barriers for liner and cover systems. EPA600-R-91-002. Prepared by Daniel, D.E. \& Estornell, P.M. for Office of Research and Development, Washington, DC

47. Ghana Landfills Guidelines (2002) Landfill guidelines of ministry of local government and rural development, environmental protection agency, Accra, Ghana

48. Ayugi G (2011) Thermal properties of selected materials for thermal insulation available in Uganda. M.Sc. Thesis Makerere University Uganda

49. Andersland $O B$, Ladanyi $B$ (2003) Frozen ground engineering, 2nd edn. Wiley, New York

Publisher's Note Springer Nature remains neutral with regard to jurisdictional claims in published maps and institutional affiliations. 